\title{
Desensitization of Postsynaptic Glutamate Receptors Contributes to High-Frequency Homosynaptic Depression of Aplysia Sensorimotor Connections
}

\author{
Evangelos G. Antzoulatos, ${ }^{1}$ Leonard J. Cleary, ${ }^{1}$ Arnold Eskin, ${ }^{2}$ Douglas A. Baxter, ${ }^{1}$ \\ and John H. Byrne ${ }^{1,3}$ \\ ${ }^{1}$ Department of Neurobiology and Anatomy, W.M. Keck Center for the Neurobiology of Learning and Memory, The University \\ of Texas-Houston Medical School, Houston, Texas 77030, USA; ${ }^{2}$ Department of Biology and Biochemistry, University of \\ Houston, Houston, Texas 77204, USA
}

\begin{abstract}
Withdrawal reflexes of Aplysia are mediated in part by a monosynaptic circuit of sensory (SN) and motor (MN) neurons. A brief high-frequency burst of spikes in the SN produces excitatory postsynaptic potentials (EPSPs) that rapidly decrease in amplitude during the burst of activity. It is generally believed that this and other (i.e., low-frequency) forms of homosynaptic depression are entirely caused by presynaptic mechanisms (e.g., depletion of releasable transmitter). The present study examines the contribution that desensitization of postsynaptic glutamate receptors makes to homosynaptic depression. Bath application of cyclothiazide, an agent that reduces desensitization of non-NMDA glutamate receptors, reduced high-, but not low-frequency synaptic depression. Thus, a postsynaptic mechanism, desensitization of glutamate receptors, can also contribute to homosynaptic depression of sensorimotor synapses.
\end{abstract}

Withdrawal reflexes of Aplysia are mediated in part by a monosynaptic circuit of sensory neurons (SNs) and motor neurons (MNs; for reviews, see Byrne et al. 1991; Cleary et al. 1995). Stimuli sufficient to elicit withdrawal reflexes evoke a high-frequency burst of spikes in the SNs (Byrne et al. 1978a,b; Walters et al. 1983; Stopfer and Carew 1996; Frost et al. 1997; Antonov et al. 1999; Phares et al. 2003). Such bursts of SN activity induce homosynaptic depression of the sensorimotor synapses, a mechanism that limits the response of MNs to peripheral stimuli (Byrne et al. 1978b; Walters et al. 1983; Stopfer and Carew 1996; Antonov et al. 1999; Phares et al. 2003).

For the past thirty years, homosynaptic depression of Aplysia sensorimotor synapses has been attributed exclusively to presynaptic mechanisms (Castellucci and Kandel 1974; Byrne 1982; Gingrich and Byrne 1985; Bailey and Chen 1988; Eliot et al. 1994; Armitage and Siegelbaum 1998; Royer et al. 2000; Gover et al. 2002; Zhao and Klein 2002). Moreover, it has been repeatedly suggested that homosynaptic depression of the sensorimotor synapse does not have a postsynaptic contribution (Castellucci and Kandel 1974; Armitage and Siegelbaum 1998; Royer et al. 2000).

The transmitter at sensorimotor synapses is most likely glutamate (Dale and Kandel 1993; Trudeau and Castellucci 1993; Schacher et al. 1997; Armitage and Siegelbaum 1998; Conrad et al. 1999; Levenson et al. 2000b; Chin et al. 2002; Antonov et al. 2003). Because glutamate receptors exhibit pronounced desensitization during high-frequency bursts (Jones and Westbrook 1996), desensitization may also contribute to high-frequency homosynaptic depression of the Aplysia sensorimotor synapse. The present study examines this issue by taking advantage of cyclothiazide, an agent that reduces desensitization of non-NMDA glutamate receptors (Patneau et al. 1993).

\section{${ }^{3}$ Corresponding author.}

E-MAIL John.H.Byrne@uth.tmc.edu; FAX (713) 500-0623.

Article and publication are at http://www.learnmem.org/cgi/doi/10.1101/ Im.61403.
Aplysia californica (150-300 g) were obtained from Alacrity Marine Biological and Marinus Inc. Animals were housed in aquaria at $15^{\circ} \mathrm{C}$ on a 12 -h/12-h light/dark cycle and were fed dried seaweed three times a week. Animals were anaesthetized by injection of isotonic $\mathrm{MgCl}_{2}(0.5 \mathrm{~mL} / \mathrm{g}$ of body weight $)$. To reduce synaptic transmission, removal and desheathing of pleural-pedal ganglia were performed while the ganglia were bathed in high$\mathrm{Mg}^{2+}$, low- $\mathrm{Ca}^{2+}$ artificial seawater $(\mathrm{pH} 7.65)$ containing the following: $400 \mathrm{mM} \mathrm{NaCl}, 10 \mathrm{mM} \mathrm{KCl}, 80 \mathrm{mM} \mathrm{MgCl}_{2}, 20 \mathrm{mM}$ $\mathrm{MgSO}_{4}, 1 \mathrm{mM} \mathrm{CaCl}_{2}, 2.5 \mathrm{mM} \mathrm{NaHCO}$, and $10 \mathrm{mM}$ HEPES. During experiments, the ganglia were bathed in high-divalent artificial seawater $(\mathrm{pH} 7.65)$, which reduces activity in polysynaptic pathways by increasing spike threshold (Byrne et al. 1978b). This solution contained the following: $368 \mathrm{mM} \mathrm{NaCl}, 8 \mathrm{mM} \mathrm{KCl}, 80$ $\mathrm{mM} \mathrm{MgCl} 2,20 \mathrm{mM} \mathrm{MgSO}_{4}, 13.8 \mathrm{mM} \mathrm{CaCl}_{2}, 2.5 \mathrm{mM} \mathrm{NaHCO}_{3}$, and $10 \mathrm{mM}$ HEPES. The desheathing and testing procedures were conducted in a static bath, which was maintained at $15^{\circ} \mathrm{C}$.

In each preparation, a single tail $\mathrm{MN}$ was identified in the pedal ganglion, based on previously described criteria (Zhang et al. 1994), and impaled with two microelectrodes (10-15 $\mathrm{M} \Omega$, filled with $3 \mathrm{M} \mathrm{KAc}$ ). One electrode was used for recording the membrane potential and the other for current injection. During testing, the $\mathrm{MN}$ was hyperpolarized to $-80 \mathrm{mV}$. Input resistance of the MN was measured by intracellular injection of a hyperpolarizing current pulse $(-1 \mathrm{nA}, 1 \mathrm{sec})$ while the $\mathrm{MN}$ was at its resting potential.

Glutamate was ejected by applying pressure (20 psi, 100 msec) to a blunt glass pipette (5 $\mu \mathrm{m}$, filled with $100 \mathrm{mM}$ L-glutamate) with a Picospritzer (General Valve Co.). The pressure applications were comparable to those used in previous studies (Dale and Kandel 1993; Trudeau and Castellucci 1993; Zhu et al. 1997; Storozhuk and Castellucci 1999). Ejections of glutamate were paired, at interpulse intervals (IPI) of 100 or $200 \mathrm{msec}$ (measured from offset of the first pulse to onset of the second). The paired-pulse ratio (PPR) was defined as the amplitude of the second response divided by the amplitude of the first response and 
multiplied by $100 \%$. While the $\mathrm{MN}$ was hyperpolarized to -80 $\mathrm{mV}$, glutamate was ejected onto the neuropil of the pedal ganglion, in the vicinity of the MN cell body, eliciting fast transient depolarizing responses in the $\mathrm{MN}$. We believe that the responses were evoked by direct action of glutamate on the $\mathrm{MN}$, and not by transmitter released from occult presynaptic neurons that were activated by the glutamate puffs, for two reasons. First, these puffs were applied in medium containing high $\mathrm{Mg}^{2+}$, high $\mathrm{Ca}^{2+}$, which prevents passive depolarizations from reaching threshold and triggering spikes (Byrne et al. 1978b; Trudeau and Castellucci 1995). Second, the kinetics of the MN responses were slower than typical EPSPs, reflecting the relatively long application of glutamate (i.e., $100 \mathrm{msec}$; cf. Fig. $1 \mathrm{~A}$ to Fig. 2A).

In experiments that examined synaptic depression, a $\mathrm{SN}$ in the ventrocaudal cluster of the pleural ganglion was impaled with a single microelectrode (10-15 M $\Omega, 3 \mathrm{M}$ KAc). Once a synaptically connected pair of cells was identified, the preparation was allowed to rest for $10 \mathrm{~min}$ before testing began. Initially,
A1
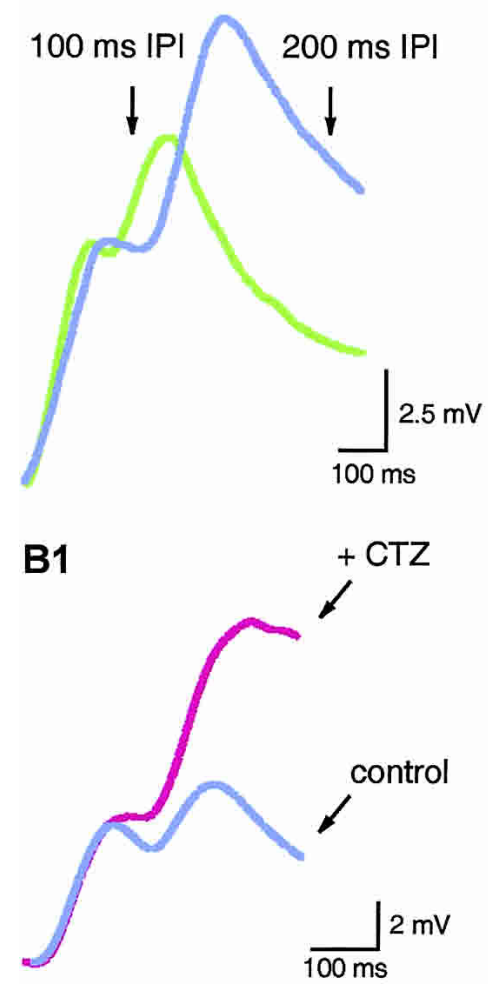

\section{A2}
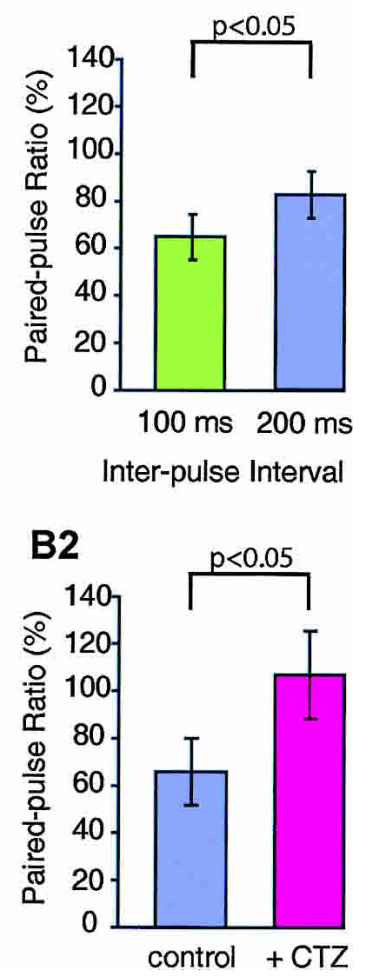

Figure 1 Desensitization of receptors limits their repetitive responses to exogenous glutamate. (A1) Two consecutive puffs of glutamate at a short interpulse interval (IPI) evoked a pair of depolarizing responses, the second of which was smaller than the first. The two traces shown are the responses of the same $M N$ to two pairs of glutamate puffs at the 100-and 200-msec intervals. (A2) Average paired-pulse ratio (PPR) ( \pm SEM) at the 100 - and 200-msec IPI. At the IPI of $100 \mathrm{msec}$, the second response to glutamate was $64.9 \% \pm 9.3 \%$ of the first response, whereas at the 200 msec IPI, the second response was $83.0 \% \pm 9.0 \%$ of the first. The difference between the two PPRs was statistically significant. This indicates that 200 msec after the first glutamate puff, there was a smaller degree of desensitization of receptors than at $100 \mathrm{msec}$ after the puff. (B1) Responses of an MN to two puffs of glutamate (IPI = $200 \mathrm{msec}$ ), before and after application of CTZ. After CTZ, the first response was unaffected, but the second response was increased. (B2) Average PPR ( \pm SEM) at the 200-msec interval, before and after CTZ. The PPR at $200 \mathrm{msec}$ IPI increased from $67.4 \% \pm 13.9 \%$ (Control) to $107.2 \% \pm 18.1 \%$ following application of CTZ (+CTZ). The difference between the two PPRs was statistically significant. while still bathed with control saline (i.e, high-divalent artificial seawater), sensorimotor synapses were tested twice at frequencies of 10 and $1 \mathrm{~Hz}$ (i.e., four tests). Each test consisted of three EPSPs evoked at either 10 or $1 \mathrm{~Hz}$, and the amplitudes of the second and third EPSPs were normalized to the amplitude of the first EPSP in each test. The tests at 10 and $1 \mathrm{~Hz}$ were alternated at 10-min intervals. The normalized amplitudes of the EPSPs were averaged for each frequency to provide the baseline amount of synaptic depression at 10 and $1 \mathrm{~Hz}$, before pharmacological treatment. Basal synaptic transmission was measured as the average peak amplitude of first EPSPs from both $10-$ and $1-\mathrm{Hz}$ tests. Only a single sensorimotor synapse was tested in each preparation. All reported values of Student's $t$ statistic refer to results of two-tailed $t$-tests for paired observations, and $F$ ratios refer to results of twoway repeated measures ANOVA. In cases in which $\mathrm{MN}$ responses summated (i.e., paired puffs of glutamate or three EPSPs elicited at $10 \mathrm{~Hz}$ ), their peak amplitude was measured from the extrapolated decay of the previous depolarization of the membrane.

Initially, we examined whether repeated, brief application of glutamate could desensitize receptors on the MN. Two puffs of glutamate were applied at an IPI of either 100 or 200 msec. Each puff of glutamate evoked fast transient depolarizations of the $\mathrm{MN}$. The response to the first glutamate pulse averaged $6.3 \pm 0.9$ $\mathrm{mV}$ (mean $\pm \mathrm{SEM}$ ). At both the 100- and 200-msec IPI, the response to the second pulse was smaller than the response to the first (Fig. 1A; $n=7, F_{(1,6)}=6.8, p<0.05$ ). In addition, the PPR at $200 \mathrm{msec}$ was significantly greater than the PPR at the 100-msec interval (Fig. 1A; $n=7, t(6)=2.7, p<0.05$ ).

Several lines of evidence indicated that the depression of the second response was not caused by nonlinear summation as might occur if the membrane potential approached the reversal potential of the response (i.e., $+10 \mathrm{mV}$; Dale and Kandel 1993). First, MNs were initially held at the hyperpolarized potential of $-80 \mathrm{mV}$, and the summated response was not greater than 15 $\mathrm{mV}$. Second, the second response could reach a higher level of depolarization at the long IPI than the short one, in the same neuron, although in both cases the membrane potential at the onset of the response was very similar (e.g., Fig. 1A1).

Depression of the $\mathrm{MN}$ response to the second glutamate puff is consistent with the hypothesis that the first puff of glutamate desensitizes the receptors, which slowly recover from desensitization during the IPI. To test this hypothesis, we treated the ganglia with cyclothiazide (CTZ), an agent that reduces desensitization of non-NMDA receptors in vertebrates (Patneau et al. 1993; Trussell et al. 1993; Arai and Lynch 1998a,b; Rozov et al. 2001). CTZ (Sigma Chemicals) was applied to the bath (dissolved in $0.2 \%$ DMSO) at a final concentration of $0.3 \mathrm{mM}$, a concentration that is frequently used in studies of vertebrate synapses (Partin et al. 1994; Fedele and Raiteri 1996; Rammes et al. 1996; Cowen and Beart 1998).

As described above, MNs were stimulated with paired pulses of exogenous glutamate at the 200-msec IPI, before and $5 \mathrm{~min}$ after the application of CTZ (Fig. 1B). The 200-msec IPI was selected to reduce temporal overlap between the two responses. The PPR was increased significantly following application of CTZ (Fig. 1B; control: $67.4 \% \pm 13.9 \%$; +CTZ: $107.2 \% \pm 18.1 \%$; $n=5$, $t(4)=3.7, p<0.05)$, whereas CTZ did not affect the amplitude of the first response to glutamate (e.g., Fig. $1 \mathrm{~B}$; control: $10.2 \pm 3.9$ $\mathrm{mV} ;+\mathrm{CTZ}: 8.7 \pm 3.5 \mathrm{mV} ; n=5, t(4)=2.4, p=0.08)$. These results indicate that a desensitization mechanism could influence the response to high-frequency bursts of activity at the sensorimotor synapse. In addition, the results imply that CTZ is an appropriate tool for examining that possibility.

To examine the possible role of desensitization at the sensorimotor synapse, SNs of the pleural ganglion were stimulated to fire three action potentials at either 10 or $1 \mathrm{~Hz}$, before and 15 


\section{A1. $10 \mathrm{~Hz}$}

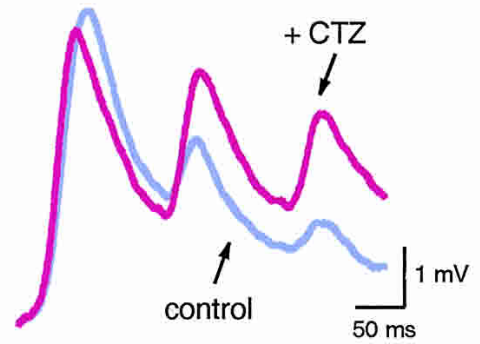

B1. $1 \mathrm{~Hz}$

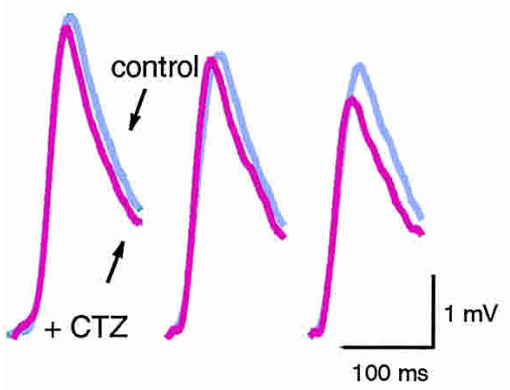

A2. $10 \mathrm{~Hz}$

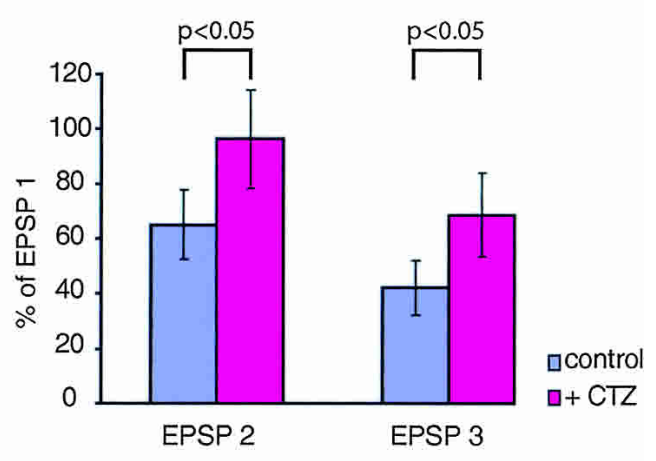

B2. $1 \mathrm{~Hz}$

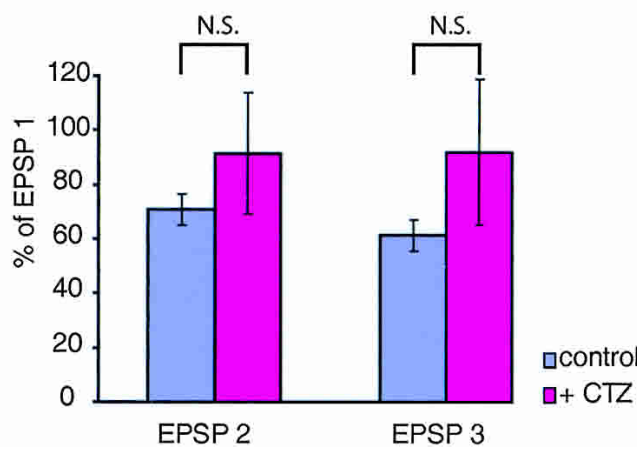

Figure 2 Desensitization of postsynaptic receptors limits the responses (EPSPs) of MNs to highfrequency stimulation of a presynaptic SN. (A1) EPSPs evoked at $10 \mathrm{~Hz}$, before and 15 min after the application of CTZ. CTZ increased the amplitudes of the second and third EPSPs, without affecting the first EPSP. (A2) Average relative amplitude of EPSPs 2 and 3 at $10 \mathrm{~Hz}$ was significantly different between control and CTZ. The same synapses were stimulated with 2 trains at $10 \mathrm{~Hz}$ and 2 trains at $1 \mathrm{~Hz}$ (see $B)$, alternating at 10-min intervals, before application of CTZ. The same stimulation regime was repeated after application of CTZ. (B1) EPSPs evoked at $1 \mathrm{~Hz}$, before and after the application of CTZ (data are from the same pair of monosynaptically connected sensory and motor neurons as in A1). The relative depression during $1 \mathrm{~Hz}$ activity was not affected by CTZ. (B2) Average relative amplitude of EPSPs 2 and 3 at $1 \mathrm{~Hz}$, from 2 trains repeated at 10-min intervals, was not significantly different between control and CTZ.

min after application of CTZ $(0.3 \mathrm{mM})$, while the monosynaptic EPSPs were recorded from the MN soma. A frequency of $10 \mathrm{~Hz}$ is in the intermediate range of the physiological activity of sensory neurons (Byrne et al. 1974, 1978a,b; Walters et al. 1983; Clatworthy and Walters 1993; Stopfer and Carew 1996; Frost et al. 1997; Antonov et al. 1999, 2003; Phares et al. 2003), and $1 \mathrm{~Hz}$ is the highest frequency that has been previously used to investigate synaptic depression in sensorimotor synapses (Castellucci and Kandel 1974; Byrne 1982; Eliot et al. 1994; Armitage and Siegelbaum 1998; Royer et al. 2000; Gover et al. 2002). Because the puff-evoked responses of MNs indicated that the receptors remain desensitized for at least $200 \mathrm{msec}$ after their activation (see Fig. 1A2), synaptic stimulation at the 100-msec intervals $(10 \mathrm{~Hz})$ should engage desensitization of postsynaptic receptors.

The SN action potentials evoked three progressively decreasing EPSPs in the postsynaptic MN (e.g., Figs. 2A1, 2B1). CTZ did not affect the peak amplitude of first EPSPs (control: $3.7 \pm 0.9$ $\mathrm{mV}$; +CTZ: $3.1 \pm 0.8 \mathrm{mV} ; n=5, t(4)=1.1, p=0.34)$, which indicates that basal transmission is not affected by postsynaptic desensitization, in agreement with a previous report (Storozhuk and Castellucci 1999). In addition, MN input resistance was stable throughout testing and was not affected by application of CTZ (control: $30.7 \pm 8.6 \mathrm{M} \Omega$; +CTZ: $30.4 \pm 9.3 \mathrm{M} \Omega$; $n=5$ ). Although MN resistance was tested at the cell body, it is assumed that if CTZ had affected the membrane resistance at postsynaptic sites, it would have also affected the resistance at the cell body, because CTZ was applied to the entire bath.

Contrary to its lack of effect on the first EPSPs, CTZ increased the peak amplitude of the second and third EPSPs during the $10-\mathrm{Hz}$ test (e.g., Fig. 2A1), thus reducing their depression (Fig. 2A2, $\left.n=5, F_{(1,4)}=11.5, p<0.05\right)$. The inhibition of desensitization may have unmasked paired-pulse facilitation (Jiang and Abrams 1998), contributing to the observed increase of EPSP2 after application of CTZ. The effect of CTZ in decreasing synaptic depression appeared to be limited to activity at $10 \mathrm{~Hz}$, as the depression evoked by $1 \mathrm{~Hz}$ in the same sensorimotor synapses was not significantly affected by CTZ (Fig. 2B; $n=5$, $\left.F_{(1,4)}=1.1, \mathrm{p}=0.34\right)$. Although the contribution of desensitization at $1 \mathrm{~Hz}$ synaptic depression in Aplysia sensorimotor synapses cannot be excluded, these results indicate that synaptic transmission at least at $10 \mathrm{~Hz}$, is partially limited by desensitization of postsynaptic receptors.

In some synapses, CTZ has been reported to affect basal, presynaptic release of neurotransmitter (Diamond and Jahr 1995; Isaacson and Walmsley 1996; Bellingham and Walmsley 1999; Ishikawa and Takahashi 2001). This does not appear to be the case in Aplysia. As mentioned above, the first EPSP was not changed following CTZ application, and CTZ did not affect EPSP amplitude at low-frequency stimulation. These results indicate that CTZ reduced the depression at $10 \mathrm{~Hz}$, not through a presynaptic effect, but by inhibiting desensitization of receptors. The efficacy of CTZ to reduce desensitization, in turn, is supported by its effects on puff-evoked responses (Fig. $1 B)$. It should be noted that this use of CTZ does not permit identification of the specific kinetic step that is affected. Therefore, it is not clear if CTZ reduced desensitization of the receptors or accelerated their recovery from desensitization. Although the receptors activated by puffs of exogenous glutamate may not be the same receptors that are activated by synaptically released glutamate, we found that CTZ affected both in a similar way. This is consistent with previous use of glutamate puffs to probe the properties of postsynaptic receptors (Dale and Kandel 1993; Trudeau and Castellucci 1993, 1995; Zhu et al. 1997; Storozhuk and Castellucci 1999; Chitwood et al. 2001). Collectively, these data support the novel finding that high-frequency homosynaptic depression of Aplysia sensorimotor synapses is caused, in part, by desensitization of postsynaptic receptors.

The present results lead to a re-evaluation of the long-held view that homosynaptic depression in Aplysia sensorimotor synapses is exclusively presynaptic (Castellucci and Kandel 1974; Byrne 1982; Gingrich and Byrne 1985; Bailey and Chen 1988; Eliot et al. 1994; Armitage and Siegelbaum 1998; Royer et al. 2000; Gover et al. 2002; Zhao and Klein 2002). However, they do not challenge previous data. The apparent contradiction is resolved by considering the frequencies of stimulation that were used in the past. The sensorimotor synapses have traditionally 
been stimulated with single spikes at frequencies $\leq 1 \mathrm{~Hz}$ (e.g., Byrne 1982). Using low frequencies of stimulation has led to an oversimplified, exclusively presynaptic, view of synaptic depression. The results presented here are still consistent with these previous reports, in that desensitization did not contribute to depression at $1 \mathrm{~Hz}$ as much as it did at $10 \mathrm{~Hz}$. Therefore, these results extend the previous view of depression to incorporate a postsynaptic contribution that emerges when SNs are activated at a high frequency.

What is the function of high-frequency synaptic depression? In several animals, synaptic depression has been related to behavioral habituation (for review, see Christoffersen 1997). However, habituation is mimicked primarily by low-frequency synaptic depression (e.g., Byrne 1982). In contrast, we do not believe that the function of high-frequency synaptic depression in Aplysia sensorimotor synapses is related to habituation. Instead, this form of synaptic depression probably contributes to the transfer of information about a single stimulus from the sensory to the motor neurons (Phares et al. 2003). Because SNs respond to individual stimuli of the peripheral tissue with shortduration, high-frequency bursts of spikes, encoding of the stimulus in the response of the MN would be limited by the burstinduced depression of sensorimotor synapses (Byrne et al. 1978b; Walters et al. 1983; Stopfer and Carew 1996; Antonov et al. 1999; Phares et al. 2003).

Finally, the finding that desensitization contributes to highfrequency synaptic depression raises the possibility that this mechanism may be regulated during learning. Both short- and long-term sensitization of withdrawal reflexes correlate with enhancement of transmitter release from SNs (Bailey and Chen 1983; Dale et al. 1988; Byrne and Kandel 1996). However, a greater amount of transmitter would be expected to activate and, subsequently, desensitize a greater fraction of the postsynaptic receptors, resulting in augmented depression of the $\mathrm{MN}$ response. To compensate for this enhanced depression, these forms of behavioral learning would be predicted to also involve mechanisms to overcome postsynaptic desensitization. One such mechanism could be up-regulation of the postsynaptic receptors, which has been associated with short- and long-term facilitation of sensorimotor synapses (Trudeau and Castellucci 1995; Zhu et al. 1997; Chitwood et al. 2001). Another protective mechanism could be enhancement of glutamate uptake from the synapse following long-term sensitization (Levenson et al. 2000a). Further experimentation will shed light on the relative contribution of postsynaptic desensitization to sensorimotor burst transmission before versus after synaptic facilitation and learning.

\section{ACKNOWLEDGMENTS}

We thank D. Fioravante and G. Phares for comments on earlier drafts of the manuscript. This work was supported by NIH grants NS 38100 (L.J.C.), NS 28462 (A.E.), and NS 19895 (J.H.B.).

The publication costs of this article were defrayed in part by payment of page charges. This article must therefore be hereby marked "advertisement" in accordance with 18 USC section 1734 solely to indicate this fact.

\section{REFERENCES}

Antonov, I., Kandel, E.R., and Hawkins, R.D. 1999. The contribution of facilitation of monosynaptic PSPs to dishabituation and sensitization of the Aplysia siphon withdrawal reflex. J. Neurosci. 19: 1043810450.

Antonov, I., Antonova, I., Kandel, E.R., and Hawkins, R.D. 2003. Activity-dependent presynaptic facilitation and Hebbian LTP are both required and interact during classical conditioning in Aplysia. Neuron 37: 135-147.

Arai, A. and Lynch, G. 1998a. The waveform of synaptic transmission at hippocampal synapses is not determined by AMPA receptor desensitization. Brain Res. 799: 230-234. 1998b. AMPA receptor desensitization modulates synaptic responses induced by repetitive afferent stimulation in hippocampal slices. Brain Res. 799: 235-242.

Armitage, B.A. and Siegelbaum, S.A. 1998. Presynaptic induction and expression of homosynaptic depression at Aplysia sensorimotor neuron synapses. J. Neurosci. 18: 8770-8779.

Bailey, C.H. and Chen, M. 1983. Morphological basis of long-term habituation and sensitization in Aplysia. Science 220: 91-93. . 1988. Morphological basis of short-term habituation in Aplysia. I. Neurosci. 8: 2452-2459.

Bellingham, M.C. and Walmsley, B. 1999. A novel presynaptic inhibitory mechanism underlies paired pulse depression at a fast central synapse. Neuron 23: $159-170$.

Byrne, J.H. 1982. Analysis of synaptic depression contributing to habituation of gill-withdrawal reflex in Aplysia californica. J. Neurophysiol. 48: 431-438.

Byrne, J.H. and Kandel, E.R. 1996. Presynaptic facilitation revisited: State and time dependence. J. Neurosci. 16: 425-435.

Byrne, J., Castellucci, V., and Kandel, E.R. 1974. Receptive fields and response properties of mechanoreceptor neurons innervating siphon skin and mantle shelf in Aplysia. J. Neurophysiol. 37: 1041-1064.

Byrne, J.H., Castellucci, V.F., Carew, T.J., and Kandel, E.R. 1978a. Stimulus-response relations and stability of mechanoreceptor and motor neurons mediating defensive gill-withdrawal reflex in Aplysia. J. Neurophysiol. 41: 402-417.

Byrne, J.H., Castellucci, V.F., and Kandel, E.R. 1978b. Contribution of individual mechanoreceptor sensory neurons to defensive gill-withdrawal reflex in Aplysia. J. Neurophysiol. 41: 418-431.

Byrne, J.H., Baxter, D.A., Buonomano, D.V., Cleary, L.J., Eskin, A., Goldsmith, J.R., McClendon, E., Nazif, F.A., Noel, F., and Scholz, K.P. 1991. Neural and molecular bases of nonassociative and associative learning in Aplysia. Ann. NY Acad. Sci. 627: 124-149.

Castellucci, V.F. and Kandel, E.R. 1974. A quantal analysis of the synaptic depression underlying habituation of the gill-withdrawal reflex in Aplysia. Proc. Natl. Acad. Sci. 71: 5004-5008.

Chin, J., Burdohan, J.A., Eskin, A., and Byrne, J.H. 2002. Inhibitor of glutamate transport alters synaptic transmission at sensorimotor synapses in Aplysia. J. Neurophysiol. 87: 3165-3168.

Chitwood, R.A., Li, Q., and Glanzman, D.L. 2001. Serotonin facilitates AMPA-type responses in isolated siphon motor neurons of Aplysia in culture. J. Physiol. 534: 501-510.

Christoffersen, G.R.J. 1997. Habituation: Events in the history of its characterization and linkage to synaptic depression. Prog. Neurobiol. 53: $45-66$.

Clatworthy, A.L. and Walters, E.T. 1993. Rapid amplification and facilitation of mechanosensory discharge in Aplysia by noxious stimulation. J. Neurophysiol. 70: 1181-1194.

Cleary, L.J., Byrne, J.H., and Frost, W.N. 1995. Role of interneurons in defensive withdrawal reflexes in Aplysia. Learn. Mem. 2: 133-151.

Conrad, P., Wu, F., and Schacher, S. 1999. Changes in functional glutamate receptors on a postsynaptic neuron accompany formation and maturation of an identified synapse. J. Neurobiol. 39: 237-248.

Cowen, M.S. and Beart, P.M. 1998. Cyclothiazide and AMPA receptor desensitization: Analyses from studies of AMPA-induced release of $\left[{ }^{3} \mathrm{H}\right]$-noradrenaline from hippocampal slices. Br. J. Pharmacol. 123: $473-480$.

Dale, N. and Kandel, E.R. 1993. L-Glutamate may be the fast excitatory transmitter of Aplysia sensory neurons. Proc. Natl. Acad. Sci. 90: $7163-7167$.

Dale, N., Schacher, S., and Kandel, E.R. 1988. Long-term facilitation in Aplysia involves increase in transmitter release. Science 239: 282-285.

Diamond, J.S. and Jahr, C.E. 1995. Asynchronous release of synaptic vesicles determines the time course of the AMPA receptor-mediated EPSC. Neuron 15: 1097-1107.

Eliot, L.S., Kandel, E.R., and Hawkins, R.D. 1994. Modulation of spontaneous transmitter release during depression and posttetanic potentiation of Aplysia sensory-motor neuron synapses isolated in culture. J. Neurosci. 14: 3280-3292.

Fedele, E. and Raiteri, M. 1996. Desensitization of AMPA receptors and AMPA-NMDA receptor interaction: An in vivo cyclic GMP microdialysis study in rat cerebellum. Br. J. Pharmacol. 117: $1133-1138$.

Frost, L., Kaplan, S.W., Cohen, T.E., Henzi, V., Kandel, E.R., and Hawkins, R.D. 1997. A simplified preparation for relating cellular events to behavior: Contribution of LE and unidentified siphon sensory neurons to mediation and habituation of the Aplysia gilland siphon-withdrawal reflex. J. Neurosci. 17: 2900-2913.

Gingrich, K.J. and Byrne, J.H. 1985. Simulation of synaptic depression, posttetanic potentiation, and presynaptic facilitation of synaptic potentials from sensory neurons mediating gill-withdrawal reflex in Aplysia. J. Neurophysiol. 53: 652-669.

Gover, T.D., Jiang, X.Y., and Abrams, T.W. 2002. Persistent,

\section{Learning \& Memory


exocytosis-independent silencing of release sites underlies homosynaptic depression at sensory synapses in Aplysia. J. Neurosci. 22: 1942-1955.

Isaacson, J.S. and Walmsley, B. 1996. Amplitude and time course of spontaneous and evoked excitatory postsynaptic currents in bushy cells of the anteroventral cochlear nucleus. J. Neurophysiol. 76: $1566-1571$.

Ishikawa, T. and Takahashi, T. 2001. Mechanisms underlying presynaptic facilitatory effect of cyclothiazide at the Calyx of Held of juvenile rats. J. Physiol. 533 (Pt 2): 423-431.

Jiang, X.Y. and Abrams, T.W. 1998. Use-dependent decline of paired-pulse facilitation at Aplysia sensory neuron synapses suggests a distinct vesicle pool or release mechanism. J. Neurosci. 18: 10310-10319.

Jones, M.V. and Westbrook, G.L. 1996. The impact of receptor desensitization on fast synaptic transmission. Trends Neurosci. 19: 96-101.

Levenson, J., Endo, S., Kategaya, L.S., Fernandez, R.I., Brabham, D.G., Chin, J., Byrne, J.H., and Eskin, A. 2000a. Long-term regulation of neuronal high-affinity glutamate and glutamine uptake in Aplysia. Proc. Natl. Acad. Sci. 97: 12858-12863.

Levenson, J., Sherry, D.M., Dryer, L., Chin, J., Byrne, J.H., and Eskin, A. 2000 b. Localization of glutamate and glutamate transporters in the sensory neurons of Aplysia. J. Comp. Neurol. 423: 121-131.

Partin, K.M., Patneau, D.K., and Mayer, M.L. 1994. Cyclothiazide differentially modulates desensitization of $\alpha$-amino-3-hydroxy-5-methyl-4-isoxazolepropionic acid receptor splice variants. Mol. Pharmacol. 46: 129-138.

Patneau, D.K., Vyklicky Jr., L., and Mayer, M.L. 1993. Hippocampal neurons exhibit cyclothiazide-sensitive rapidly desensitizing responses to kainate. J. Neurosci. 13: 3496-3509.

Phares G.A., Antzoulatos, E.G., Baxter, D.A., and Byrne, J.H. 2003. Burst-induced synaptic depression and its modulation contribute to information transfer at Aplysia sensorimotor synapses: Empirical and computational analyses. J. Neurosci. (in press).

Rammes, G., Swandulla, D., Collingridge, G.L., Hartmann, S., and Parsons, C.G. 1996. Interactions of 2,3-benzodiazepines and cyclothiazide at AMPA receptors: Patch clamp recordings in cultured neurones and area CA1 in hippocampal slices. Br. J. Pharmacol. 117: 1209-1221.

Royer, S., Coulson, R.L., and Klein, M. 2000. Switching off and on of synaptic sites at Aplysia sensorimotor synapses. J. Neurosci. 20: $626-638$.
Rozov, A., Jerecic, J., Sakmann, B., and Burnashev, N. 2001. AMPA receptor channels with long-lasting desensitization in bipolar interneurons contribute to synaptic depression in a novel feedback circuit in layer 2/3 of rat neocortex. J. Neurosci. 21: 8062-8071.

Schacher, S., Wu, F., and Sun, Z.Y. 1997. Pathway-specific synaptic plasticity: Activity-dependent enhancement and suppression of long-term heterosynaptic facilitation at converging inputs on a single target. J. Neurosci. 17: 597-606.

Stopfer, M. and Carew, T.J. 1996. Heterosynaptic facilitation of tail sensory neuron synaptic transmission during habituation in tail-induced tail and siphon withdrawal reflexes of Aplysia. J. Neurosci. 16: 4933-4948.

Storozhuk, M.V. and Castellucci, V.F. 1999. Some receptor properties in motor neurons of an Aplysia withdrawal reflex. Neurochem. Res. 24: $1443-1447$.

Trudeau, L.E. and Castellucci, V.F. 1993. Excitatory amino acid neurotransmission at sensory-motor and interneuronal synapses of Aplysia californica. J. Neurophysiol. 70: 1221-1230.

. 1995. Postsynaptic modifications in long-term facilitation in Aplysia: Upregulation of excitatory amino acid receptors. J. Neurosci. 15: $1275-1284$.

Trussell, L.O., Zhang, S., and Raman, I.M. 1993. Desensitization of AMPA receptors upon multiquantal neurotransmitter release. Neuron 10: $1185-1196$.

Walters, E.T., Byrne, J.H., Carew, T.J., and Kandel, E.R. 1983. Mechanoafferent neurons innervating tail of Aplysia. I. Response properties and synaptic connections. J. Neurophysiol. 50: 1522-1542.

Zhang, F., Goldsmith, J.R., and Byrne, J.H. 1994. Neural analogue of long-term sensitization training produces long-term (24 and $48 \mathrm{~h}$ ) facilitation of the sensory-to-motor neuron connection in Aplysia. J. Neurophysiol. 72: 778-784.

Zhao, Y. and Klein, M. 2002. Modulation of the readily releasable pool of transmitter and of excitation-secretion coupling by activity and by serotonin at Aplysia sensorimotor synapses in culture. J. Neurosci. 22: 10671-10679.

Zhu, H., Wu, F., and Schacher, S. 1997. Site-specific and sensory neuron-dependent increases in postsynaptic glutamate sensitivity accompany serotonin-induced long-term facilitation at Aplysia sensorimotor synapses. J. Neurosci. 17: 4976-4986.

Received March 18, 2003; accepted in revised form June 23, 2003. 


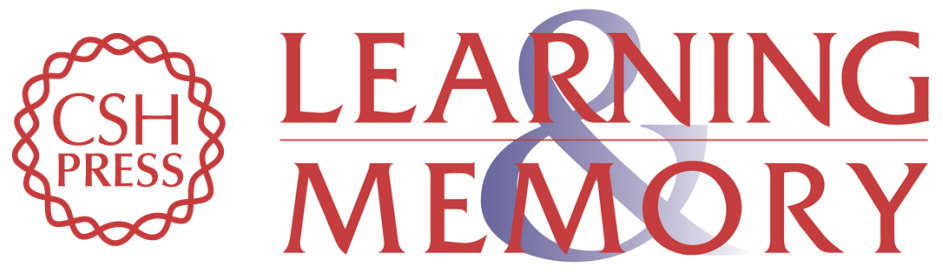

\section{Desensitization of Postsynaptic Glutamate Receptors Contributes to High-Frequency Homosynaptic Depression of Aplysia Sensorimotor Connections}

Evangelos G. Antzoulatos, Leonard J. Cleary, Arnold Eskin, et al.

Learn. Mem. 2003, 10:

Access the most recent version at doi:10.1101//m.61403

References This article cites 51 articles, 23 of which can be accessed free at: http://learnmem.cshlp.org/content/10/5/309.full.html\#ref-list-1

License

Email Alerting

Receive free email alerts when new articles cite this article - sign up in the box at the Service top right corner of the article or click here. 